\title{
Isotopic characteristics and water interaction of Ifni Lake and spring of Tifnoute valley (high Atlas Mountains, Morocco, North of Africa)
}

\begin{abstract}
Geochemical and isotopic investigations were carried out to indicate the interaction process between Ifni lake water and high valley of Tifnoute springs. A total of 18 water samples were collected and analyzed. The Ifni lake constitutes a veritable water resource in the study area, and this water can be the origin of alimentation the springs located in the high valley the Tifnoute. This study aims to improve the interaction between Ifni lake water and the springs of high valley of Tifnoute. It is mainly focused to identify the origin of groundwater recharge and mineralization. The environmental isotope (deuterium $(\delta 2 \mathrm{H})$ and oxegen-18 $(\delta 18 \mathrm{O})$ ) measurements allowed understanding the hydro geochemical process, the origin of the mineralization of the water. Also the results identify the relationship between the waters of Ifni Lake and the spring's water of high valley of Tifnoute. The isotopic compositions reveal that the origin of Ifni lake water is meteoric, and the water infiltrates directly in the groundwater without any evaporation.
\end{abstract}

Keywords: Mountain water, isotopic process, hydrogen and oxygen isotopes, lakegroundwater interaction
Volume 2 Issue 3 - 2018

\author{
Kacem Lamyaa,' Agoussine Mbark, ${ }^{2}$ \\ Igmoullan Brahim, ${ }^{3}$ Amar Hicham, ${ }^{4}$ Mokhtari \\ Soraya, ${ }^{5}$ Ait Brahim Yassine ${ }^{6}$ \\ 1,3 Department of Earth Science, Cadi Ayyad University, Morocco \\ 2Department of Industrial Engineering, Ibn Zohr University, \\ National School of Applied Science, Morocco \\ ${ }^{4}$ Laboratory of Data Processing, Recognition of Seismic Waves \\ and Structure of the Earth, Morocco \\ ${ }^{5}$ Department of Toubkal National Park, Regional Direction of \\ Water and Forest and Fight against Desertification High Atlas, \\ Morocco \\ 'Laboratory of Applied Geology and Geo-Environment, Ibn \\ Zohr University, Morocco
}

Correspondence: Kacem Lamyaa, Department of Earth Science, Cadi Ayyad University, Morocco,

Email: lamyaa.kacem@gmail.com

Received: May 01, 2018 | Published: May 10, 2018

\section{Introduction}

Morocco is one of the countries that must cope with an important water deficit. ${ }^{1}$ Also, these regions are particularly sensitive to variability induced from climate changes. ${ }^{2-5}$ Groundwater and surface water constitute a single complex and interconnected system. ${ }^{6,7}$ In many mountainous rural areas in Morocco the spring's water represents a source of dirking water. In the high valley of Tifnoute, the spring's water is used for human consumption. Generally, water in these mountain area characterized by low mineralization. Also this area characterized by the highest mountain, and natural lake in Morocco. Water from Ifni Lake outflows by springs which are located just downstream from the lake. The people in the high valley of Tifnoute used spring water for drinking and irrigation. ${ }^{8}$ The water isotopes $\left({ }^{18} \mathrm{O},{ }^{2} \mathrm{H}\right)$ are excellent tracers for determining the origin of groundwater; they are widely used in studying the natural water circulation and groundwater movement, also due to their conservative characteristics of moving with $\mathrm{H}_{2} \mathrm{O}$ molecule., ${ }^{9}, 10$ Using of isotopic tracers is an effective approach for investigating the complex hydrological processes of groundwater range of spatial and temporal scales. ${ }^{11-17}$ Also spring, precipitation and surface water respond to the isotope signature of atmospheric water. ${ }^{18-20}$ The changes in stable isotopes overtime and in space can provide a better understanding of aquifer recharge and discharge. ${ }^{21-23}$ In the study area the Ifni lake constitutes a natural tower of water witch aliments a majority of springs, this area has never been the subject of isotopic study. The aim of this work is to improve the ground-surface water interaction, using isotopic process. Moreover, stable isotope $\left(\delta^{2} \mathrm{H}, \delta^{18} \mathrm{O}\right)$ and chemical analyses reveal a clear relation between Ifni Lake and some springs water. The isotopic analysis of the waters allowed us to understand the hydro geochemical process, the origin of the mineralization of the water and also to identify the relationship between the waters of Ifni Lake and the spring's water of high Tifnoute Valley.

\section{Materials and methods}

\section{Study area}

The high valley of Tifnoute is located in the Moroccan High Atlas between latitudes $30^{\circ} 59^{\prime}$ and $31^{\circ} 5^{\prime}$ North, and longitudes $7^{\circ} 56^{\prime}$ and $7^{\circ} 48^{\prime}$ West (Figure 1), one of the interesting area in the National Park of Toubkal. The area characterized by semi-arid climate with important precipitations, and dendritic hydrographic network (Figure 1). The high valley of Tifnoute catchment it's characterized by highest elevations, a greater degree of slopes, ${ }^{24}$ and irregular terrain..$^{25}$ Geologically, the study area is dominated by volcanic and metamorphic rocks essentially are: andesite, basalt, granite and rhyolite. In the Tifnoute Valley, part of the ancient massif, three units of plutonic rocks have been defined. ${ }^{26}$ The Askaoun intrusion showing quartz diorites and granodiorites, intrusion of Imourkhssen, formed of coarse-grained granite, and Ougougane intrusions made of finegrained granite.

\section{Observations and hypotheses}

We find the very important water resources in the high valley of Tifnoute, springs and surface waters. Ifni Lake is the natural dam of water in this area, which alimented the important springs. Mainly, some springs waters located under lake level had similar chemistry composition of Ifni lake water. The relationship between Ifni lake and 
springs water is very special: the waters of a "small watershed" coming from the melting of snow and accumulate in the lake, then during all the year this water is transit by natural underground conduit whose exit it at the nearer springs (Tinkhar N'ifni and Tamda). Tamda is the name given by the population in this region to a small topographical water depression (Figure 2) situated at $2192 \mathrm{~m}$ of altitude in the south East of the lake. When water reaches a level at Ifni lake (Reference rock situated at an altitude of $2320 \mathrm{~m}$ ), the water gushes a week after in the Tamda spring (Figure 3). So, this suggestion can explain the relationship between Ifni Lake and Tamda spring water and we used isotopic analyses to verify this observation.

\section{Water sampling and analysis}

A total of 18 water samples were collected from high valley of Tifnoute springs, and Ifni Lake during the period of May 2015. The spring's location was determined using a global positioning system (GPS) (Figure 1). Eventually, samples were collected in glass bottles for stable isotopes analysis. The samples were preserved and transported in laboratory. Stable isotope of waters deuterium and oxygen-18 compositions were analyzed using cavity ring down spectrometry (Picarro L2120) at Laboratory of Applied Geology and Geo-Environment, Ibn Zohr University. The values are expressed in Standard Mean Ocean Water (SMOW) in per mill \%.

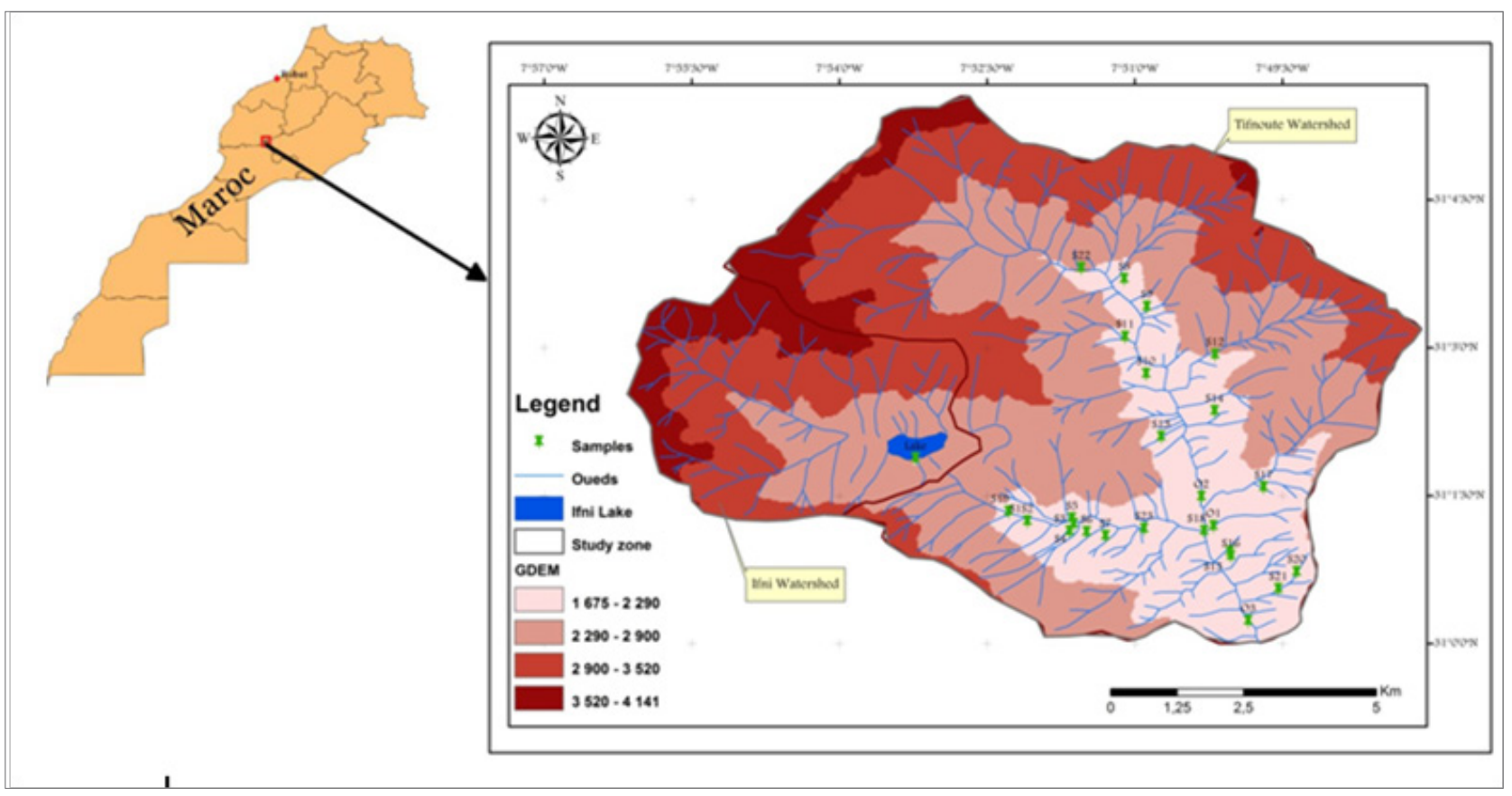

Figure I Map of location the study area and water samples.

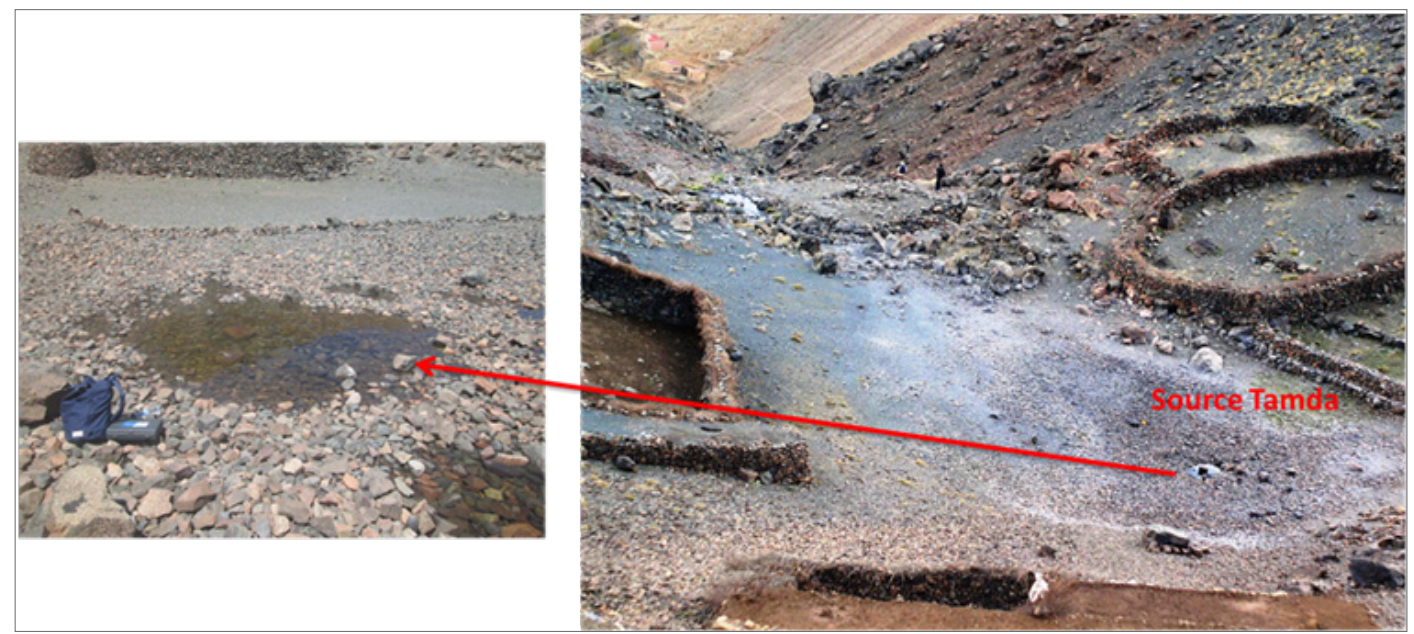

Figure 2 Photograph showing the Tamda spring. 


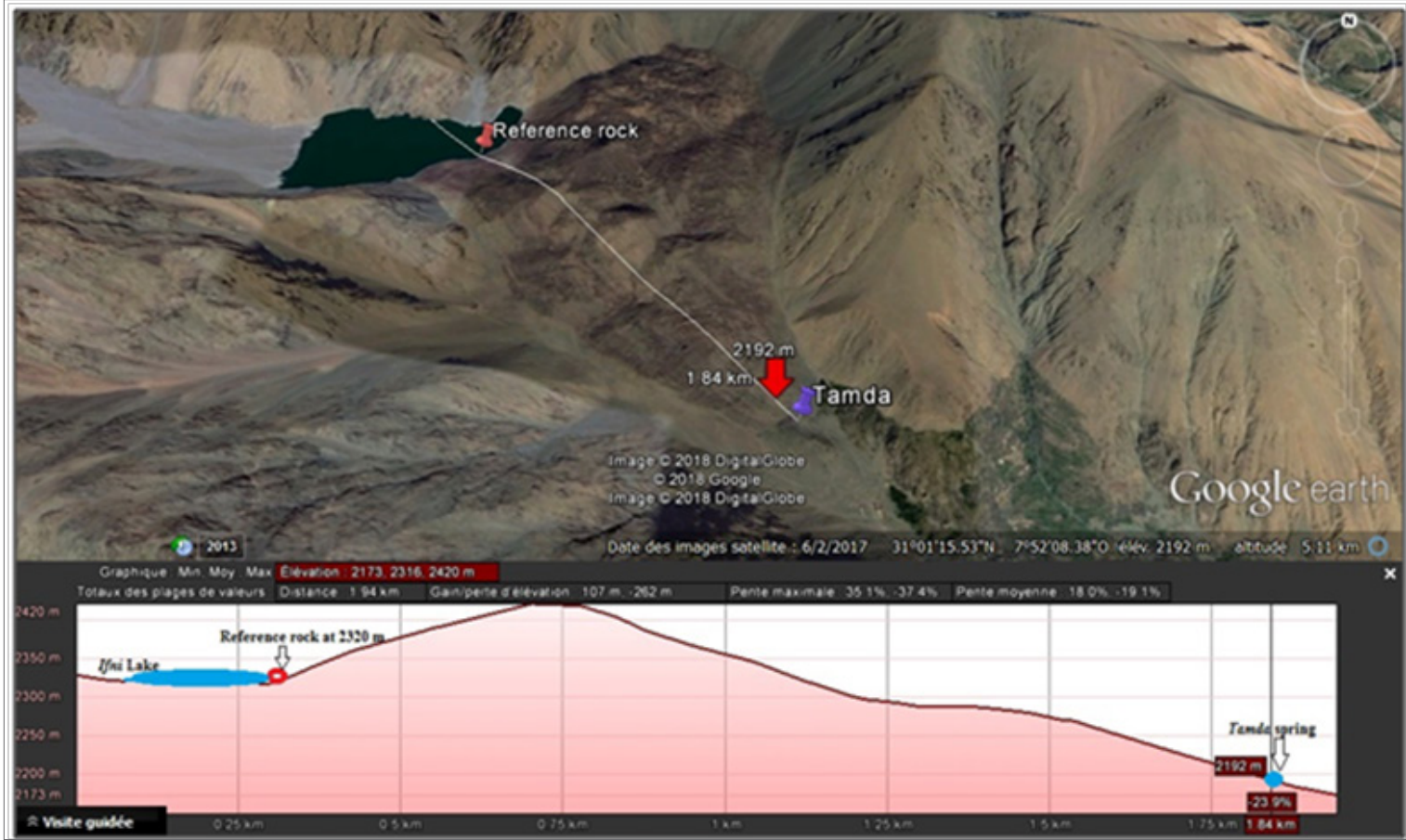

Figure 3 Relationship between Ifni lake and Tamda spring water.

\section{Results and discussion}

Generally, the spring waters in this mountain area are characterized by low mineralization. ${ }^{8}$ The Ifni lake is located at $2320 \mathrm{~m}$ in this mountain area, mainly this lake and spring waters fed by atmospheric precipitation and snow. Ifni lake water characterized by $80 \mu \mathrm{s} / \mathrm{cm}$ of conductivity, and 8.4 of $\mathrm{pH}$. The water composition is rich in magnesium, calcium and bicarbonate ions. Isotopic data (Table 1) reveal the $\delta^{18} \mathrm{O}$ values of samples range from -8.13 (S5) to -10.28 (S22) $v s \%$ V-SMOW, whereas the $\delta^{2} \mathrm{H}$ values range from -55.89 (S6) to -67.83 (S8) $v s \%$ V-SMOW. The water sample collected from Ifni lake presents this isotopic content: $\delta^{18} \mathrm{O}=-8,43$ and $\delta^{2} \mathrm{H}=-59 \%$ (Table 1). The diagram (Figure 4) show the water samples plot compared to the global meteoric water line (GMWL), ${ }^{27}$ and local meteoric water line (LMWL) ${ }^{28}$ Usually, deviations in isotopic compositions away from meteoric water line may results from processes of evaporation. ${ }^{29-31}$ The results (Figure 4) show that the most of water samples plot on (GMWL) and have isotopic signatures close to those of meteoric water, which explains that the origin of waters is meteoric and it was infiltrate directly. We can subdivide the water samples into three groups according to their isotopic signatures:

A. First group (Group A) is presented by the Ifni lake and O1, S1, S19 (Tamda spring), S5, S7, S6, S13 waters, these samples are located under the (LMWL). The waters of this group are characterized by a low mineralization, so the waters infiltrated quickly and the interaction water-rock is very weak. We can explain these results, and the similar chemical composition of these group waters that is a strong relationship between Ifni Lake and this group of waters, which the effect of evaporation is less marked. Also, the Tamda spring and Ifni lake waters can constitutes a similar isotopic signature and chemistry composition. We can confirm the suggestion about Tamda-Ifni lake water relationship.

B. Second group (Group B) is represented by waters of O2, S15, S9,
$\mathrm{S} 23, \mathrm{~S} 12, \mathrm{~S} 17$ and the third group (Group C) is represented by the S8, S22 springs. These samples are located near the (LMWL) and are characterized by isotopic signature low of $\delta^{18} \mathrm{O}$ composition, which indicates that the source of waters recharge come from high altitudes and low temperatures recharges.

Table I Isotopic contents of water samples in the high valley of Tifnoute

\begin{tabular}{llll}
\hline Water samples & $\boldsymbol{\delta}^{18}$ O SMOW & $\boldsymbol{\delta}^{2} \mathbf{H}$ SMOW & $\begin{array}{l}\text { Altitude } \\
(\mathbf{m})\end{array}$ \\
\hline Ifni Lake & $-8,42475$ & $-58,97725$ & 2327 \\
SI & $-8,34175$ & $-57,04875$ & 2177 \\
S5 & $-8,13075$ & $-56,076$ & 2059 \\
S6 & $-8,22025$ & $-55,8925$ & 1962 \\
S7 & $-8,371$ & $-56,532$ & 1895 \\
S8 & $-10,099$ & $-67,838$ & 2202 \\
S9 & $-9,3$ & $-62,3355$ & 2143 \\
S12 & $-9,00875$ & $-60,1065$ & 2267 \\
S13 & $-8,19$ & $-54,50425$ & 2076 \\
S15 & $-9,011$ & $-61,295$ & 1775 \\
S17 & $-9,37625$ & $-61,70825$ & 2073 \\
S18 & $-8,37675$ & $-56,5475$ & 1885 \\
OI & $-8,3675$ & $-57,93525$ & 1716 \\
O2 & $-9,6985$ & $-65,373$ & 1774 \\
S19 (Tamda spring) & $-8,1685$ & $-56,91725$ & 2183 \\
O3 & $-9,4385$ & $-62,7845$ & 1717 \\
S22 & $-10,28325$ & $-67,6355$ & 2142 \\
S23 & $-9,59475$ & $-64,12825$ & 1872 \\
\hline & & &
\end{tabular}


To identify the altitudes of the recharge conditions of these waters, we used the altitudinal gradient established by Cappy ${ }^{32}$ using the equation $1.33,34$

$$
\delta^{18} O \%=(-0.002 \times \text { Altitude })-3(1)
$$

The results (Figure 5) show that the waters originate from the high altitudes areas between 3000-3600 m, come from the high Moroccan Atlas. Therefore, the springs would be recharged by the fissure water and precipitation.

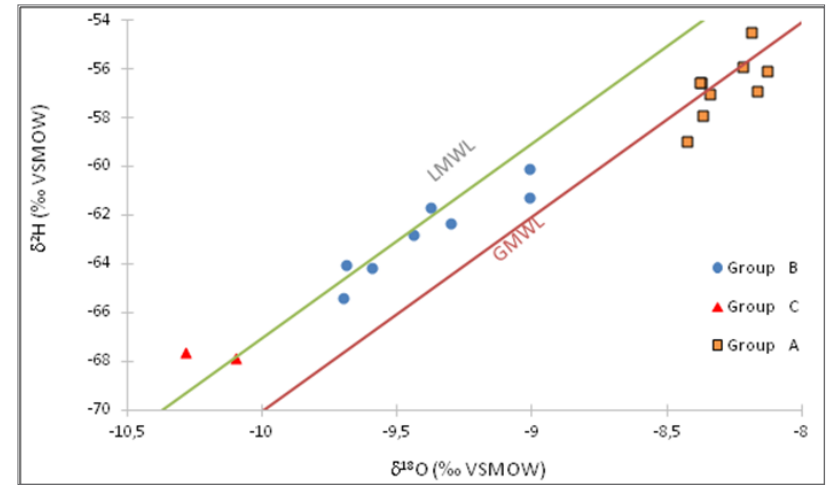

Figure $4 \delta 2 \mathrm{H}$ versus $\delta 18 \mathrm{O}$ diagram of water as compared to the global meteoric water line (GMWL) and the local meteoric water line (LMWL).

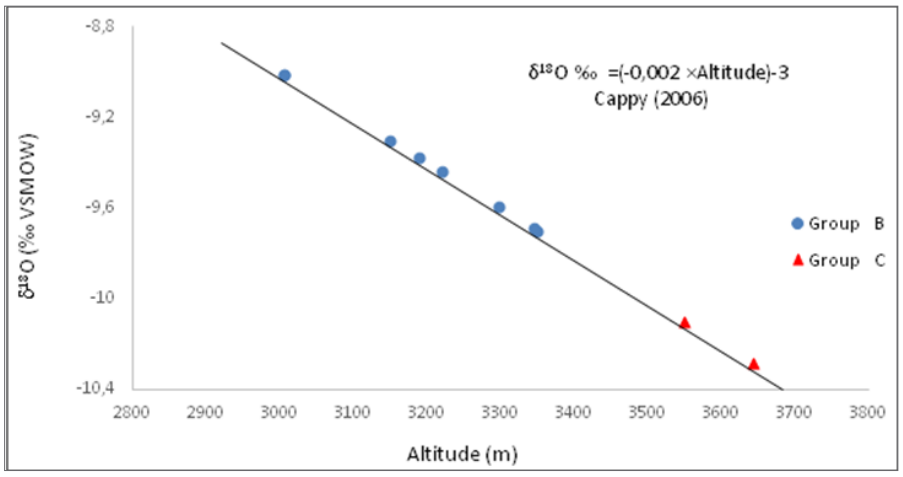

Figure 5 Relationship between $\delta I 80$ in the water samples and their recharge elevation according with altitude gradient of Cappy. 32

\section{Conclusion}

The high valley of Tifnoute is a mountainous study area characterized by very important softly water resources, the Ifni Lake is a natural dam situated at $2320 \mathrm{~m}$, and aliments the springs water in this region. To indicate that the origin of this water is the lake we organized the different companies to collect the maximum of information from population. Also, to prove the interaction lakesprings the isotopic investigations were defined. The results showed that high precipitation water and the snow melt are the origin of Ifni Lake. The $\delta^{18} \mathrm{O}$ and $\delta^{2} \mathrm{H}$ data in springs water indicating that the water origin is meteoric, and a local recharge of the study area waters from areas at $3600 \mathrm{~m}$ altitudes, which correspond to the High Atlas Mountains (Jbel Toubkal).

\section{Acknowledgement}

None.

\section{Conflict of interest}

The authors declare there is no conflict of interest.

\section{References}

1. Agoussine M, Saidi ME, Igmoullan B. Recognition of the water resources in the Ouarzazate basin (South-East Morocco). Bull of the Scientific Institute of Rabat. Earth Sciences part. 2004;26:81-92.

2. Agoussine M, Bouchaou L. Major problems of water management in Morocco. Sci Planet Changes/Drought. 2004;15.

3. Born K, Fink AH, Paeth H. Dry and wet periods in the north western Maghreb for present day and future climate conditions. Meteorol Z. 2008; $17: 533-551$

4. Lgourna Z, Warner N, Bouchaou L, et al. Elucidating the sources and mechanisms of groundwater salinization in the Ziz Basin of southeastern Morocco. J Environ Earth Sci. 2014;73(1):77-93.

5. Ait Brahim Y, Benkaddour A, Agoussine M, et al. Origin and salinity of groundwater from interpretation of analysis data in the mining area of Oumjrane, Southeastern Morocco. Environ Earth Sci. 2015;74(6):47874802 .

6. Owor M, Taylor R, Mukwaya C, et al. Groundwater/surface water interactions on deeply weathered surfaces of low relief: evidence from lake Victoria and Kyoga, Uganda. Hydrogeology journal. 2011;19(7):14031420 .

7. Shaw G, White ES, Gammons CH. Characterizing groundwater - lake interactions and its impact on lake water quality. Journal of hydrology. 2013;492(7):69-78.

8. Kacem L, Agoussine M, Igmoullan B, et al. Feature Interaction of Lake Water and Springs and Evaluation of Hydrochemical Water Composition of the Highest Natural Mountain Lake of Morocco: Ifni Lake (High Atlas Mountains, Morocco - North of Africa). Water Resources -Springer. 2006;43(2):395-401

9. Adomako A, Osae S, Akiti TT. et al. Geochemical and isotopic studies of groundwater conditions in the Densu River Basin of Ghana. Environ Earth Sci. 2011;62(5):1071-1084.

10. Xin L, Xianfang S, Yinghua Z, et al. Spatio-temporal variations of $\mathrm{d}^{2} \mathrm{H}$ and $\mathrm{d}^{18} \mathrm{O}$ in precipitation and shallow groundwater in the Hilly Loess Region of the Loess Plateau, China. Environ Earth Sci. 2011;63:1105-1118.

11. Clark ID, Frjtz P. Environmental isotopes in hydrogeology. New York: Lewis Publishers. 1997.

12. Alyamani MS. Isotopic composition of rainfall and groundwater recharge in the western province of Saudi Arabia. J Arid Environ. 2001;49(4):751760 .

13. Gibson J, Edwards T, Birks S, et al. Progress in isotope tracer hydrology in Canada. Hydrol Process. 2005;19(1):303-327.

14. Song X, Liu X, Xia J, et al. A study of interaction between surface water and ground-water using environmental isotope in Huaisha River basin. $\mathrm{Sci}$ China. 2006;49(12):1299-1310.

15. Carol E, Kruse E, Mas-Pla J. Hydrochemical and isotopical evidence of ground water salinization processes on the coastal plain of Samborombo'n Bay, Argentina. J Hydrol. 2009;365(3):335-345.

16. Wassenaar LI, Athanasopoulos P, Hendry MJ. Isotope hydrology of precipitation, surface and ground waters in the Okanagan Valley, British Columbia, Canada. J Hydrol. 2011;411:37-48.

17. Cui BL, Li XY. Characteristics of stable isotope and hydrochemistry of 
the groundwater around Qinghai Lake, NE Qinghai-Tibet Plateau, China. Environ Earth Sci. 2012;71(3):1159-1167.

18. Yurtsever Y, Gat JR. Atmospheric waters. In: Gat JR, Gonfiantini R, editors. Stable Isotope Hydrology: Deuterium and Oxygen-18 in the Water Cycle. Tech-nical Report Series 210, IAEA, 1981.

19. De Oliveira ACV, Lima AS. Spatial variability in the stable isotopes of mod-ern precipitation in the northwest of Iberia. Isotopes Environ. Health Stud. 2010;46(1):13-26.

20. Elke Bozau, Hans-Joachim Stärkb, Gerhard Strauch. Hydrogeochemical characteristics of spring water in the Harz Mountains, Germany. Chemie der Erde. 2013;73(3):283-292.

21. Aquilina L, Ladouche B, Dorfliger N. Recharge processes in karstic systems investigated through the correlation of chemical and isotopic composition of rain and spring-waters. Appl Geochem. 2005;20(12):2189-2206.

22. Barbieri $M$, Boschetti $T$, Petitta $M$, et al. Stable isotopes $\left({ }^{2} \mathrm{H},{ }^{18} \mathrm{O}\right.$ and $87 \mathrm{Sr} / 86 \mathrm{Sr}$ ) and hydrochemistry monitoring for groundwater hydrodynamics analysis in a karst aquifer (Gran Sasso, Central Italy). Appl Geochem. 2005;20(11):2063-2081.

23. Tallini M, Falcone RA, Carucci V, et al. Isotope hydrology and geochemical modeling: new insights into the recharge processes and water-rock interactions of a fissured carbonate aquifer (Gran Sasso, central Italy). Environ Earth Sci. 2014;72(12):4957-4971.

24. Kacem L, Igmoullan B, Mokhtari S, et al. Morphometric characterization of upstream mountainous watershed using geographic information system GIS: high valley of Tifnoute High Moroccan Atlas. Journal of biodiversity and environmental sciences. 2014;5(6):62-66.

25. Kacem L, Agoussine M, Igmoullan B, et al. Mapping soil erosion risk using Analytic hierarchy process (AHP) method: A case of mountainous sub-watershed, high valley of Tifnoute (High Moroccan Atlas). Geo-EcoTrop. 2017;41(3):493-502.
26. Toummite A. The Late Proterozoic Granitoids of the Tifnoute Valley (Central Anti-Atlas): an example of a post-collisional magmatism of juvenile origin in a metacratonic context. National Thesis, University of Ibn Zohr - Agadir. 2012;4-170.

27. Craig H. Isotopic variations in meteoric waters. Science. 1961;133:17021703.

28. Ouda B, El Hamdaoui A, Ibn Majah M. Isotopic composition of precipitation at Three Moroccan stations influenced by oceanic and Mediterranean air masses, IAEA, Vienna. TECDOC. 2004;1453:125-140.

29. Domenico PA, Schwartz FW. Physical and Chemical Hydrogeology. New York: Wiley. 1990. p. 824.

30. Drever JI. The geochemistry of natural waters, surface and groundwater environments. 3rd ed. Prentice Hall, London. 1997;436.

31. Karakaya N, Karakaya MC, Nalbantçılar MT, et al. Relation between spring-water chemistry and hydrothermal alteration in the Şaplica volcanic rocks, Şebinkarahisar (Giresun, Turkey). Journal of Geochemical Exploration. 2004;93(1):35-46.

32. Cappy S. Hydrogeological characterization of the upper Draa catchment: Morocco. University Bonn. 2006;216.

33. Ait Brahim Y, Benkaddour A, Agoussine M, et al. Origin and salinity of groundwater from interpretation of analysis data in the mining area of Oumjrane, Southeastern Morocco. Environ Earth Sci. 2015. 74(6):47874802 .

34. Msilimba G, Wanda E. Microbial and geochemical quality of shallow well water in high-density areas in Mzuzu city in Malawi. Physics and chemistry of the earth. 2013;66:173-180. 